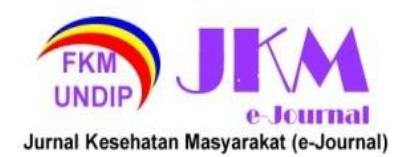

\author{
JURNAL KESEHATAN MASYARAKAT (e-Journal) \\ Volume 9, Nomor 6, November 2021 \\ ISSN:2715-5617 / e-ISSN: 2356-3346 \\ http://ejournal3.undip.ac.id/index.php/ikm
}

\title{
PENERAPAN MANAJEMEN PENCEGAHAN COVID-19 DI PUSKESMAS X KABUPATEN WONOSOBO
}

\author{
Nurul Aini Hidayah* \\ Fakultas IImu Keolahragaan, Universitas Negeri Semarang, Jalan Sekaran Gunungpati \\ *Corresponding author:nurulainihidayah90@gmailcom
}

\begin{abstract}
ABSTRAK
Tercatat dari bulan Maret - 1 Desember 2020, ada 63,5 juta kasus COVID-19 di seluruh dunia yang dicatat oleh WHO Penelitian ini bertujuan untuk mengetahui bagaimana penerapan manajemen pengendalian COVID-19 di fasilitas layanan kesehatan khususnya puskesmas. Metode yang digunakan adala deskriptif observasional. Instrumen yang digunakan adalah lembar observasi, wawancara dan studi dokumentasi. 83,3\% Pengendalian sudah diterapkan di Puskesmas $X$. Penerapan pengendalian COVID-19 dan penggunaan APD di puskesmas belum terlaksana $100 \%$
\end{abstract}

Kata kunci:COVID-19, fasilitas, kesehatan, manajemen, pengendalian

\section{LATAR BELAKANG}

Pada saat ini, dunia sedang mengalami pandemi COVID-19 yang merupakan sumber bahaya biologis bagi manusia. Tercatat dari bulan Maret - 1 Desember 2020, ada 63,5 juta kasus COVID-19 di seluruh dunia yang dicatat oleh WHO. Sedangkan di Indonesia terdapat 543,975 kasus terkonfirmasi COVID-19. Sedangkan pada periode yang sama, kasus aktif terkonfirmasi COVID-19 di Provinsi Jawa Tengah terdapat 55,896 (10,4\%) kasus terkonfirmasi COVID-19 yang merupakan peringkat nomor 3 tertinggi setelah Provinsi DKI Jakarta dengan 136,861 (25,4\%) kasus dan Provinsi Jawa Timur dengan 61,883 $(11,5 \%)$ kasus menurut peta sebaran COVID19 pada laman Satuan Tugas Penanganan COVID-19 Indonesia. Ada 17 kabupaten/kota dari 35 kabupaten/kota di Jawa Tengah yang tergolong ke dalam zona merah COVID-19 yang artinya risiko penularan virus tersebut sangat tinggi. Kabupaten Wonosobo termasuk ke dalam zona merah COVID-19 bersama dengan Kabupaten Temanggung, Rembang, Pati, Sragen, Tegal, Brebes, Kendal, Batang, Brebes, Kota Semarang, Salatiga, Surakarta serta Tegal.

Kasus terkonfirmasi infeksi COVID-19 pada tenaga kesehatan di Kabupaten Wonosobo sendiri, per bulan Sepember 2020 terdapat sebanyak 47 orang. Sedangkan per bulan September 2020, ada sebanyak 17\% atau 9 dari 51 orang pegawai Puskesmas $X$ yang terinfeksi COVID-19. Bersamaan dengan Puskesmas $Y$ yang memiliki 12 kasus terinfeksi COVID-19 pada pekerjanya di bulan yang sama. Kedua puskesmas ini juga sempat mengalami penutupan tempat kerja sementara karena banyaknya kasus positif pada tenaga kesehatan di fasilitas layanan kesehatan tersebut. Sampai pada bulan Mei tahun 2021, sudah ada $27 \%$ atau 14 dari 51 pegawai yang terinfeksi COVID-19 di Puskesmas X.Puskesmas $X$ sudah menjalankan beberapa prosedur pengendalian COVID-19, mereka juga sudah menyediakan APD bagi seluruh tenaga kesehatan dan karyawan terkait. Namun, berdasarkan wawancara yang dilakukan dengan salah satu stakeholder terkait, APD yang tersedia di Puskesmas X Kabupaten Wonosobo, dirasa masih tidak sesuai oleh standar serta kebijakan yang diambil dalam pengendalian COVID-19 di tempat kerja belum bekerja secara optimal. Berdasarkan Peraturan Menteri Kesehatan Republik Indonesia (Permenkes RI) Nomor 27 Tahun 2017, kegiatan Pencegahan Pengendalian Infeksi (PPI) di fasilitas layanan kesehatan adalah upaya untuk mencegah dan meminimalkan terjadinya infeksi pada pasien, petugas, pengunjung, dan masyarakat sekitar fasilitas pelayanan kesehatan. ${ }^{1}$ Komite atau Tim PPI bertugas melaksanakan kegiatan kegiatan pengkajian, perencanaan, pelaksanaan, monitoring dan evaluasi, dan pembinaan. Komite atau Tim PPI merupakan organisasi nonstruktural pada Fasilitas Pelayanan Kesehatan yang mempunyai fungsi utama menjalankan PPI serta menyusun kebijakan pencegahan dan pengendalian infeksi termasuk pencegahan infeksi yang bersumber dari masyarakat berupa Tuberkulosis, HIV (Human Immunodeficiency Virus), dan infeksi menular lainnya. ${ }^{1}$

Tujuan kewaspadaan standar adalah mengurangi risiko transmisi patogen melalui darah (bloodborne) dan patogen lain dari 


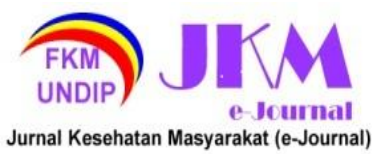

JURNAL KESEHATAN MASYARAKAT (e-Journal)

Volume 9, Nomor 6, November 2021

ISSN:2715-5617 / e-ISSN: 2356-3346

http://ejournal3.undip.ac.id/index.php/ikm

sumber yang diketahui dan tidak diketahui. Kewaspadaan standar adalah kewaspadaan pengendalian infeksi tingkat dasar minimal yang digunakan dalam merawat semua pasien.Tenaga kesehatan memerlukan kewaspadaan sesuai transmisi tambahan lainnya untuk melindungi diri dan mencegah transmisi di tempat pelayanan kesehatan. ${ }^{2}$ Tenaga kerja yang merawat pasien COVID-19 harus selalu mengimplementasikan kewaspadaan kontak dan droplet.Kewaspadaan airborne harus diterapkan untuk prosedur yang menghasilkan aerosol dan perawatan-perawatan dukungan.Meskipun penggunaan APD adalah tindakan pengendalian yang paling mudah terlihat dalam mencegah penyebaran infeksi, penggunaan APD hanyalah salah satu langkah PPI dan tidak dapat diandalkan sebagai strategi pencegahan utama.Tanpa adanya pengendalian administratif dan mekanik yang efektif, manfaat APD terbatas, sebagaimana dideskripsikan dalam panduan WHO tentang pencegahan dan pengendalian infeksi saluran pernapasan akut berisiko epidemi dan pandemi dalam pelayanan kesehatan. ${ }^{3}$

Pengendalian-pengendalian yang dapat dilakukan pada masa pandemi COVID19 adalah pengendalian mekanik, administratif serta penggunaan alat pelindung diri (APD) yang sesuai. Pengendalian mekanik ini bersifat mengisolasi manusia dengan sumber bahaya. ${ }^{4}$ Beberapa pengendalian risiko bahaya berdasarkan Center of Disease Control and Prevention atau CDC dan Tim Mitigasi Dokter pada Masa Pandemi COVID19. Pengendalian administratif mencakup memastikan tersedianya sumber daya untuk langkah-langkah pencegahan dan pengendalian infeksi (PPI), seperti infrastruktur yang sesuai, penyusunan kebijakan PPI yang jelas, fasilitasi akses uji laboratorium, triase dan penempatan pasien yang sesuai, termasuk pemisahan area/ruang tunggu khusus untuk pasien dengan gejala saluran pernapasan, rasio staf-pasien yang memadai, dan pelatihan bagi staff. ${ }^{5}$

Penelitian ini bertujuan untuk mengetahui bagaimana penerapan manajemen pengendalian COVID-19 di Puskesmas X Kabupaten Wonosobo. Serta bertujuan khusus untuk mengetahui bagaimana penerapan pengendalian mekanik, administratif serta alat pelindung diri (APD) COVID-19 di Puskesmas X Kabupaten Wonosobo. Sehingga diharapkan bagi Puskesmas tersebut dapat menekan adanya infeksi COVID-19 di lingkungan kerja yaitu Puskesmas X Kabupaten Wonosobo.

\section{METODE PENELITIAN}

Jenis dan rancangan penelitian ini menggunakan metode penelitian deskriptif kualitatif. Metodologi kualitatif adalah prosedur penelitian yang mengkaji kualitas dari sebuah hubungan, kegiatan, dan situasi yang digambarkan kedalam sebuah deskripsi berupa kata tertulis atau lisan dari orang-orang dan perilaku yang dapat diamati mendeskripsikan manajemen pengendalian COVID-19 di Puskesmas X Kabupaten Wonosobo. Sedangkan waktu penelitian dilaksanakan pada tanggal 7 April 2021 bertempat di Puskesmas $X$ Kabupaten Wonosobo.

Sumber informasi dalam penelitian ini diperoleh dari dua jenis yaitu sumber informasi data primer dan data sekunder. Informan kunci yang berasal dari Puskesmas $X$ ini adalah koordinator tim Pencegahan Pengendalian Infeksi (PPI) serta koordinator tim Keselamatan dan Kesehatan Kerja (K3). Serta informan tambahan yang merupakan karyawan Puskesmas X Kabupaten Wonosobo. Data sekunder pada penelitian ini diperoleh dari dokumen-dokumen yang ada di Puskesmas X Kabupaten Wonosobo meliputi gambaran umum/profil Puskesmas $X$ serta dokumen lain yang mendukung terkait gambaran pencegahan dan pengendalian infeksi terkait COVID-19 yang ada.

Instrumen yang digunakan dalam penelitian ini adalah lembar observasi pedoman pengendalian COVID-19 pada layanan kesehatan yang berupa checklist, lembar pedoman wawancara, lembar studi dokumentasi serta alat perekam yang digunakan untuk merekam wawancara dengan pengambil kebijakan terkait. Teknik pengambilan data dalam penelitian ini dilakukan melalui beberapa tahap, yaitu: teknik pengambilan data primer dilakukan dengan cara melakukan pengamatan (observasi) dan wawancara dengan informan. Teknik pengambilan data sekunder dilakukan dengan cara melakukan analisis terhadap dokumendokumen yang terdapat di Puskesmas $\mathrm{X}$ Kabupaten Wonosobo.

Setelah diperoleh data dari hasil wawancara dan observasi, maka selanjutnya dilakukan pemeriksaan keabsahan data dan analisis data. Kemudian dilakukan penyajian data secara deskriptif dan evaluasi sesuai pedoman serta penarikan kesimpulan dari hasil penelitian.Pemeriksaan keabsahan data 


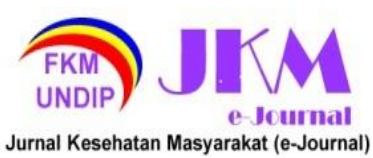

dalam penelitian ini dilakukan dengan triangulasi.

\section{HASIL DAN PEMBAHASAN}

Responden dalam penelitian ini berjumlah 5 informan, yaitu terdiri dari
JURNAL KESEHATAN MASYARAKAT (e-Journal)

Volume 9, Nomor 6, November 2021

ISSN:2715-5617 / e-ISSN: 2356-3346

http://ejournal3.undip.ac.id/index.php/ikm

Tabel 1Karakteristik Responden

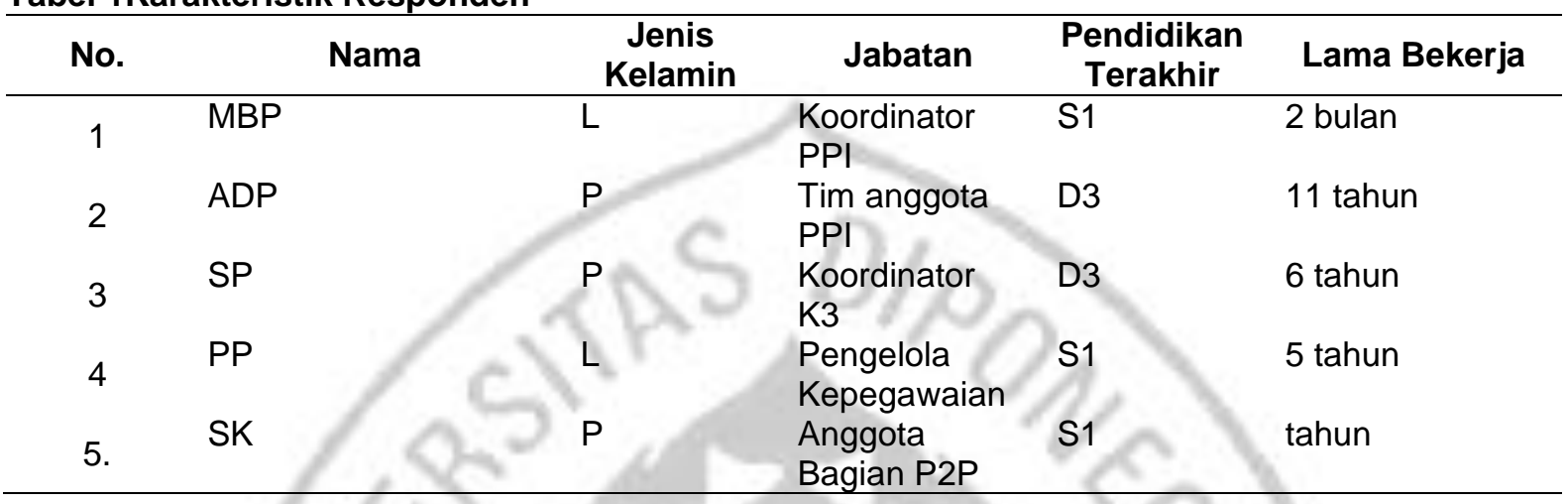

Pengamatan dilakukan di dua unit yaitu upaya kesehatan perorangan atau UKP dan upaya kesehatan masyarakat atau UKM, Ada beberapa aspek yang diamati dalam penerapan pengendalian mekanik, pedoman yang digunakan untuk mengamati pengendalian ini adalah :

1. OSHA Panduan Kerja Aman untuk Petugas Kesehatan dan Karyawan tahun 2020.

2. OSHA no. 0339 tentang panduan persiapan tempat kerja untuk COVID-19 tahun 2020.

3. WHO tentang kesehatan dan keselamatan kerja bagi petugas kesehatan tahun 2021.

Sedangkan aspek yang diamati dalam pengendalian mekanik adalah :

1. Memasang sekat pembatas antara pengunjung dan petugas.

2. Memasang garis penanda jarak

3. Memperbaiki ventilasi di tempat kerja.

4. Menggunakan HEPA filter (High Efficiency Particulate Air

5. Mengatur posisi tempat duduk antar karyawan.

6. Membedakan akses pintu masuk dan keluar.

7. Menyediakan wastafel atau hand sanitizer di setiap pintu akses.

8. Pemisahan tempat pakai dan lepas APD. koordinator Pencegahan Pengendalian Infeksi (PPI), anggota tim PPI, Koordinator K3 dan pengelola kepegawaian. Berikut daftar responden Puskesmas $\mathrm{X}$ dijelaskan pada tabel1.

Bagian P2P

Berdasarkan hasil pengamatan dan wawancara, ada dua unit di Puskesmas X Kabupaten Wonosobo. Yaitu unit kesehatan perorangan dan unit kesehatan masyarakat. Serta ada beberapa pengendalian yang sudah dan belum dilakukan di UKP dan UKM Puskesmas $X$. Dapat disimpulkan bahwa pengendalian mekanik untuk unit kesehatan perorangan atau UKP baru mencapai $50 \%$ dengan 4 dari 8 poin yang diamati. Dan untuk unit kesehatan masyarakat yaitu sebanyak $37 \%$ pengendalian yang sudah dilaksanakan dengan 3 dari 8 poin yang diamati.

Selain pengendalian mekanik, ada pula aspek pengolahan limbah. Pengolahan limbah bagi fasilitas layanan kesehatan perlu diperhatikan di masa pandemi COVID-19 agar supaya limbah infeksius tidak mencemari lingkungan dan manusia. Pengelolaan limbah COVID-19 diatur dalam pedoman WHO tentang kesehatan dan keselamatan kerja bagi petugas kesehatan tahun 2021 serta di dalam Pedoman Kementerian Kesehatan Republik Indonesia tentang Pengelolaan Limbah Rumah Sakit Rujukan, Rumah Sakit Darurat dan Puskesmas Yang Menangani Pasien COVID-19 tahun 2020. ${ }^{1}$

Berdasarkan hasil pengamatan terdapat kegiatan pengolahan limbah yang sudah dilaksanakan mencapai skor 83,3\% dengan 15 dari 18 poin sudah tercapai. Untuk penjelasanya akan dijelaskan di tabel 4.6 adalah sebagai berikut : 


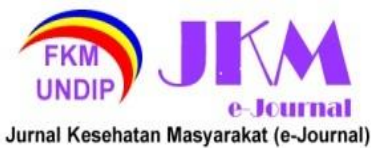

JURNAL KESEHATAN MASYARAKAT (e-Journal)
Volume 9, Nomor 6, November 2021
ISSN:2715-5617 / e-ISSN: 2356-3346
http://ejournal3.undip.ac.id/index.php/ikm

Tabel 2 Pengolahan Limbah

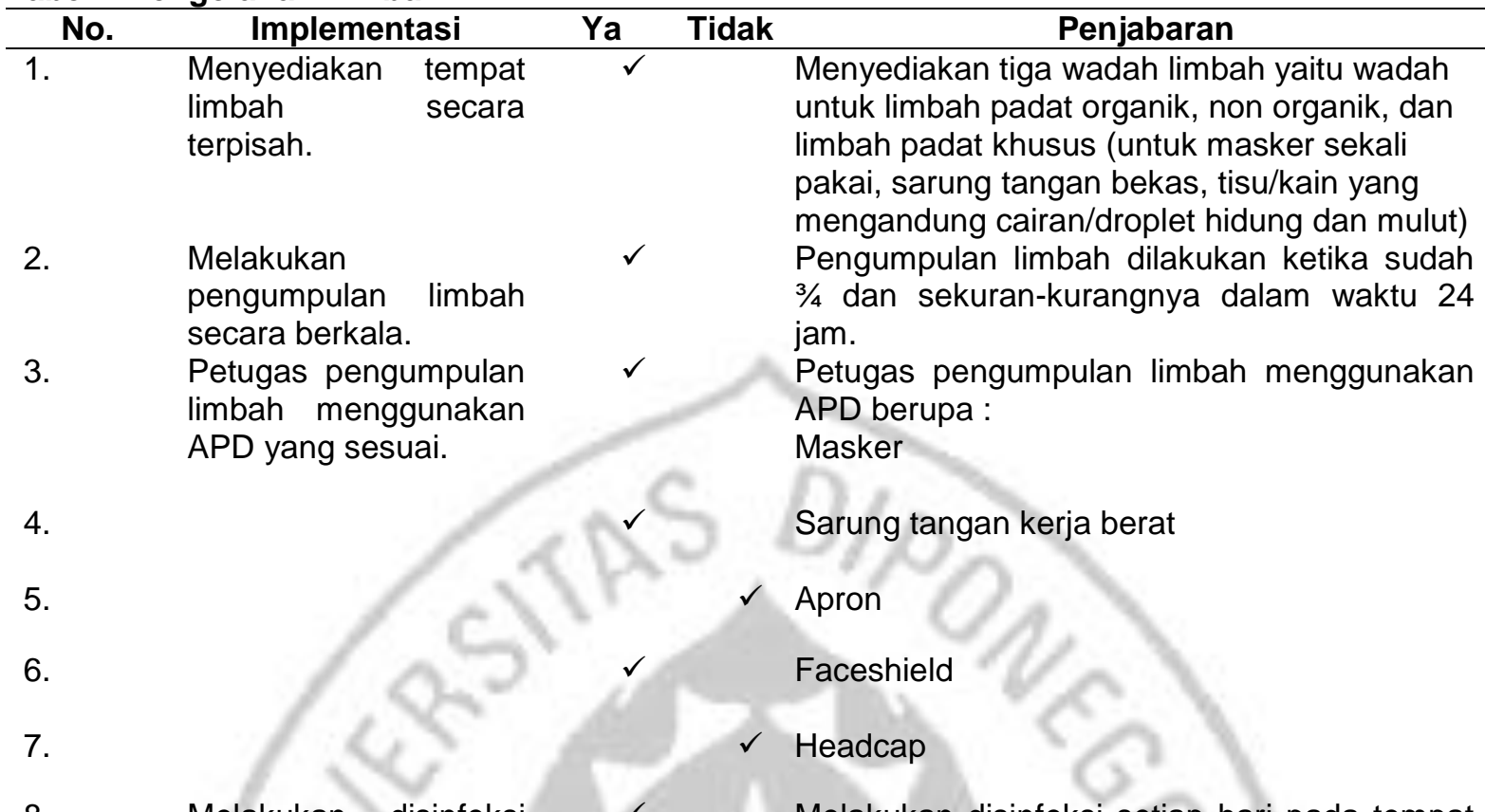

8. Melakukan disinfeksi pada tempat pembuangan limbah.

9. Limbah padat khusus ditempatkan dalam tempat limbah B3.

10. Limbah B3 dimasukkan ke dalam tempat khusus.

11. Limbah medis harus diangkut setiap 24 jam sekali.

12.

Pengangkutan limbah medis B3 harus menggunakan APD

13. lengkap.

Melakukan disinfeksi setiap hari pada tempat pembuangan limbah.

Limbah ditempatkan di tempat dengan tanda "biohazard"

Limbah ditempatkan di tempat dengan tanda "biohazard"

Cukup jelas.

APD yang digunakan adalah :

Masker N95 atau ekuivalen

Faceshield

14.

15.

16.

17

Pengangkutan harus menggunakan

Sarung tangan kerja berat

Gown/ hazmat

.

khusus.

18. Menggunakan IPAL

Sepatu bot.

Pengangkutan limbah medis B3 harus menggunakan transportasi khusus.

Melakukan instalasi IPAL untuk mengolah limbah medis cair.

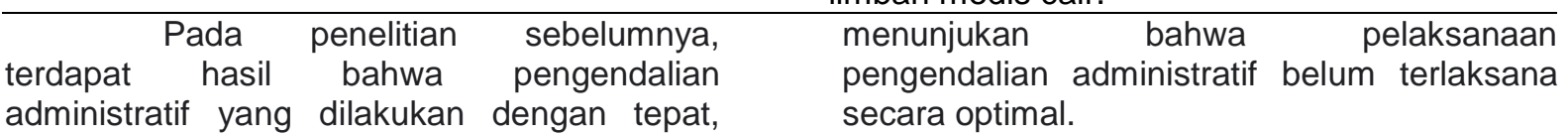
administratif yang dilakukan dengan tepat, seperti pola manajemen penerimaan pasien selama pandemi COVID-19, dapat menjamin keamanan layanan kesehatan yang diberikan kepada masyarakat tanpa penularan. (OSHA, 2020) Sementara itu, hasil di lapangan

Pada pengamatan aspek alat pelindung diri, peneliti meggunakan pedoman yang dikeluarkan oleh Kementerian Kesehatan Republik Indonesia tentang APD yang digunakan oleh tenaga kesehatan pada masa 


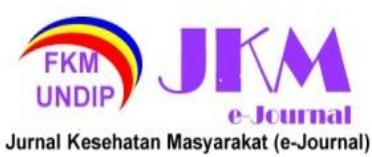

pandemi COVID-19. Peggunaan APD sudah tepat pada tenaga kesehatan di Puskesmas $X$ tersebut. Akan tetapi, masalah muncul pada saat melepas masker atau APD lainya. Belum diadakanya pelatihan pelepasan APD dan seringnya melepas masker secara tidak sengaja pada saat selesai jam layanan puskesmas menimbulkan adanya potensi penularan infeksi COVID-19 antar sesama karyawan.

\section{KESIMPULAN}

Kegiatan manajemen pengendalian COVID-19 belum berjalan secara maksimal. Dengan belum adanya modul/SOP tertulis yang tersedia serta belum dilaksanakanya kegiatan monitoring dan evaluasi rutin terkait program Pencegahan dan Pengendalian Infeksi (PPI) di Puskesmas X. Kurangnya dukungan berupa tenaga ahli, peralatan serta pejabat terkait yang bertugas secara langsung memantau program pengendalian COVID-19 dapat menghambat kegiatan-kegiatan terkait PPI. ${ }^{6}$ Kegiatan pengendalian mekanik yang ada di Puskesmas $X$ sudah berjalan dengan baik namun masih perlu adanya peningkatan pengendalian pada beberapa poin sehingga perlu adanya dukungan dari karyawan serta stakeholder terkait agar supaya tetap terjaga keadaanya. Kegiatan pengendalian administrasi masih belum berjalan dengan sempurna, dengan belum adanya pelatihan terkait penggunaan APD, pelepasan APD, dekontaminasi APD serta pelatihan pengolahan limbah. Dengan ditemukanya kasus terinfeksi COVID-19 pada kluster pekerja puskesmas, salah satu faktornya dapat disinyalir karena tidak patunnya penggunaan APD pada petugas, serta tidak adanya pelatihan terkait PPI yang cukup memadai.

\section{REKOMENDASI}

Berdasarkan hasil penelitian tentang penerapan manajemen pengendalian COVID19 (studi kasus di Puskesmas X Kabupaten Wonosobo), saran yang dapat direkomendasikan antara lain

1. Bagi Koordinator Bidang Pencegahan dan Pengendalian Infeksi (PPI)

1) Melakukan kegiatan pelatihan terkait pemakaian, pembuangan serta pelepasan APD dan pengelolaan limbah kepada pekerja, monitoring dan evaluasi terkait program Pencegahan dan Pengendalian Infeksi (PPI).
2) Membuat dokumen atau panduan pengendalian administratif, mekanik dan APD yang terkait PPI khususnya pada masa pandemi COVID-19 berdasarkan panduan WHO tentang Pencegahan dan Pengendalian Infeksi (PPI) di layanan kesehatan.

3) Melakukan kegiatan pelatihan, monitoring dan evaluasi terkait Pencegahan dan Pengendalian Infeksi (PPI).

2. Bagi Koordinator Bidang Keselamatan dan Kesehatan Kerja (K3)

1) Melakukan penilaian risiko di tempat kerja secara teratur untuk paparan risiko lain untuk kesehatan dan keselamatan di tempat kerja yang diperkuat oleh pandemi COVID-19 dan menilai efektivitas tindakan pencegahan.

2) Menambah ruangan untuk melepas serta menggunakan Alat Pelindung Diri (APD) secara terpisah.

3. Bagi Koordinator Bidang Kesehatan Lingkungan

1) Memasang instalasi Instalasi Pembuangan Air Limbah (IPAL) untuk pengolahan limbah cair dan infeksius.

2) Membuat dokumen terkait pemantauan tindakan perbaikan hasil penelitian.

4. Bagi Masyarakat

1) Masyarakat dan lintas sektor perlu mendukung dan berpartisipasi dalam pelaksanaan program pencegahan pengendalian COVID-19 di Puskesmas $X$ secara bersama-sama demi tercapainya tujuan program.

2) Masyarakat yang memiliki gejala penyakit pernafasan diharap dapat meningkatkan kesadaran diri untuk menggunakan masker medis tiga lapis apabila berkunjung ke puskesmas.

\section{DAFTAR PUSTAKA}

1. Keputusan Menteri Kesehatan Republik Indonesia. (2020). Keputusan Menteri Kesehatan Republik Indonesia Nomor HK.01.07/MenKes/413/2020 Tentang Pedoman Pencegahan dan Pengendalian Corona Virus Disease 2019 (Covid-19). MenKes/413/2020, 2019, 207.

2. OSHA. (2020). Guidance on Preparing Workplaces for COVID-19. US Department of Labor, 1-35.

3. Direktur Jenderal Pelayanan Kesehatan. (2020). Petunjuk Teknis Alat Pelindunng Diri (APD). Petunjuk Teknis Alat Pelindung 
Diri APD, April, 1-3.

4. Prevention, C. for D. C. and. (2020). Use Personal Protective Equipment (PPE) When Caring for Patients with Confirmed or Suspected COVID-19 Before caring for patients with confirmed or suspected COVID-19, healthcare personnel (HCP) must: COVID-19 Personal Protective Equipment (PPE) for Health. CDC, 6-7. www.cdc.gov/coronavirus

5. WHO. (2020). Penggunaan rasional alat perlindungan diri untuk penyakit coronavirus ( COVID-19) dan pertimbangan jika ketersediaan sangat terbatas. World Health Organization, 6 April(Panduan Sementara), 1-31. WHO/2019-nCov/IPC_PPE_use/2020.2

6. Unit, C. (2020). Pencegahan dan Pengendalian Infeksi ( PPI ) untuk Virus COVID-19. World Health Organization. 